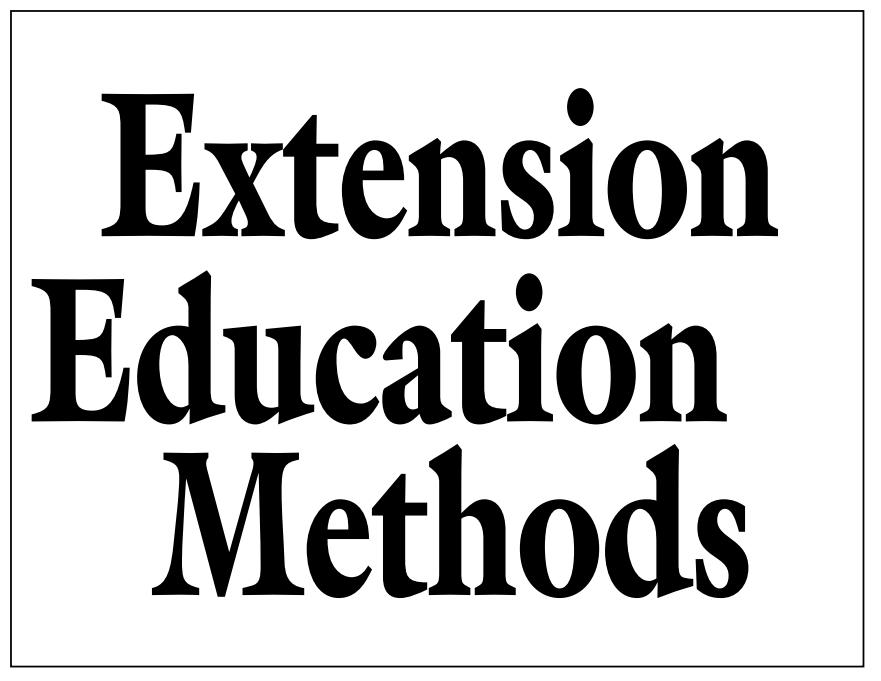

\section{Ohio State University Extension Nursery, Landscape, and Turf Team: Teamwork at Its Best}

\author{
Gary Y. Gao, ${ }^{1}$ James A. Chatfield, ${ }^{2}$ \\ Erik A. Draper, ${ }^{3}$ and Joseph F. Boggs ${ }^{4}$
}

AdDitional Index wORds. program delivery, partnership, green industry, team, teamwork

Summary. The Ohio State University (OSU) Extension Nursery, Landscape, and Turf Team (ENLTT) is an innovative and interdisciplinary team comprised of extension agents, extension specialists, researchers, teaching faculty, university arboretum staff, and research assistants. ENLTT has greatly improved the process of acquisition, delivery, and support of accurate, practical, and timely educational resources through interdisciplinary and industry partnerships. The award-winning weekly electronic newsletter Buckeye Yard and Garden Line (BYGL) has been the focal point of our teamwork since 1993. An ornamental research circular, authored and edited by

Authors would like to thank Ohio Nursery and Landscape Association for thei generous financial support and Ohio State University Extension administration for their vision and support. The cost of publishing this paper was defrayed in part by the payment of page charges. Under postal regulations, this paper therefore must be hereby marked advertisement solely to indicate this fact.

${ }^{1}$ Horticulture extension agent and assistant professor, Ohio State University Extension, Clermont County, P.O. Box 670, 1000 Locust Street, Owensville, OH 45160 ; to whom reprint requests should be addressed.

${ }^{2}$ Assistant state specialist, Department of Horticulture and Crop Science, The Ohio State University, and District Horticulture Specialist and Assistant Professor, Ohio State University Extension, Northeast District, OARDC/OSU, Wooster, OH, 44691 .

${ }^{3}$ Horticulture extension agent and Instructor, Ohio State University Extension, Geauga County, 14269 Claridon-Troy Rd., P.O. Box 387, Burton OH 44021.

${ }^{4}$ District horticulture specialist and assistant professor, Ohio State University Extension, Southwest District, and Horticulture Industry Agent, Ohio State University Extension, Hamilton County, 11100 Winton Rd., Cincinnati, OH 45218.
ENLTT members, remains the most requested publication from the Section of Communication and Technology, Ohio Agricultural Research Development Center, OSU. Strong partnership with the green industry in Ohio has resulted in the financial commitment of more than $\$ 230,000$ from the Ohio Nursery and Landscape Association since 1993.

ENLTT members have improved themselves as a result of educating each other through weekly BYGL conference calls from April to October, taking study tours, and conducting joint educational programs. Twenty-two commodity or issue teams, such as, Floriculture Team, Vegetable Crops Team, Tree Fruit Team, Forestry Team, Agronomic Crops Team, Sustainable Agriculture Team, and Dairy Team, have been formed in OSU Extension due to the success of ENLTT.

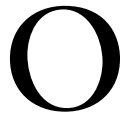
rganizational survival now demands speed, flexibility, and creativity (Lipman-Blumen and Leavitt, 1999.) The Ohio State University Extension Nursery, Landscape, and Turf Team was formed in the face of budget crisis in 1993 to effectively deliver accurate, practical, and timely educational resources to the green industry and gardening public. ENLTT has evolved into a highly successful and self-directed team. As defined by Donald Weiss (Weiss, 1990), "each team member in an effective team exhibits the characteristics of leadership in one way or other or to one degree or another and, as a group, teammates use peer pressure to manage the process and task behaviors to make the team function effectively. In an effective team, each member of the team contributes to its success, with different people voluntarily, often unconsciously, playing a variety of roles at different times." Working as a team, ENLTT members have been able to energize each other and accomplish many important tasks for the green industry, gardening public, and extension offices. More than twenty commodity or issue teams such as the Floriculture Team, Vegetable Crops Team, Tree Fruit Team, Forestry Team, Agronomic Crops Team, Sustainable Agriculture Team, and Dairy Team, have been formed in OSU Extension due to the success of ENLTT.

\section{Why was ENLTT formed?}

ENLTT was formed in 1993 in response to a severe state funding reduction in 1992 and the subsequent early retirement of several horticulture faculty at OSU, including the landscape and nursery specialist. Although funding reduction problems were reversed, prospects to refill these positions were bleak at that time. Since the green industry in Ohio still needed to be served, the chairman of the OSU horticulture department called a university and industry focus meeting. During the meeting, several faculty members at the department commented that there would not be a landscape and nursery extension program since OSU lost the state extension specialist position. However, others strongly disagreed since there were still many extension agents, district extension specialists, horticultural researchers, and state extension specialists of other academic departments that worked on nursery and landscape issues and programs. The idea was proposed to form a team to meet the needs of the green industry, instead of relying on one state extension specialist. Green industry leaders embraced the idea.

A group of state specialists, district specialists, and 
extension agents met numerous times and formed the Extension Nursery and Landscape Team in 1993. The team presented a core proposal to the Ohio Nursery and Landscape Association (ONLA) for funding. The team originally was comprised of 21 members. The name of the team was later changed to the Extension Nursery, Landscape, and Turf Team to more correctly reflect the makeup of the team. ENLTT now consists of 38 members with 14 extension agents, five extension associates, two district extension specialists, four state extension specialists, eight research or teaching faculty, one research assistant, two arboretum staff, one U.S. Department of Agriculture scientist, and one industry scientist.

Another key factor contributing to the formation of ENLTT was that the OSU Extension administration had developed a program for extension agents' specialization. Consequently, extension agents may declare their areas of specialization such as landscape horticulture, nursery crops, fruit crops, integrated pest management, and consumer horticulture. They are able to concentrate their efforts on their areas of specialization rather than trying to be everything to everyone. Extension agents are also highly encouraged to work cross county lines to help each other out when needed. When a ENLTT member organizes a program, that team member can call upon other members to speak on subjects in their area of specialization. The first ENLTT membership directory was developed in 1995 where the expertise of each team member was clearly identified. It has been revised each year and made available to extension offices, during educational seminars, field days, industry trade show, and advisory committee meetings.

\section{Key accomplishments of ENLTT}

Key accomplishments of ENLTT include the Buckeye Yard and Garden Line, the Ornamental Research Circular, the revision of three certification manuals for ONLA, greatly improved communication with industry partners, enhancement of the OSU Nursery Short Course, addition of the Plant Health Care Workshop and Regional Plant Material Schools, and "the reunion of minds," a regularly scheduled information exchange between researchers and extension personnel.

The most important accomplishment of the ENLTT is the Buckeye Yard and Garden Line, a weekly electronic newsletter written for nursery, landscape, and turf industry, and extension offices (Chatfield et al., 1996.) BYGL is written by 10 ENLTT members based on a Tuesday morning conference calls of extension agents, specialists and other contributors in Ohio. BYGL regularly receives excellent reviews from both the green industry and extension agents since it provides timely and practical solutions to the problems that the green industry and extension offices faced from April to October. It has also become an invaluable tool for answering customers' questions. In 1999, more than 1,000 people received BYGL by email, 213 by fax $, 3,511$ by newsletter subscription, and 47,600 through newspapers (Gao et al., 2000). In 1999, BYGL survey respondents estimated that BYGLincreased their profitability by $\$ 122,500$ due to correct pest identification, timely solutions, reduced pest pesticide usage, better informed employees, time savings, and improved customer service (Gao et al., 2000.) BYGL was also made available on the Internet at <http:/ / bygl.osu.edu> via the OSU Horticulture and Crop Science in Virtual Perspective web site. There were 18,527 hits from January to October 2000.

The second major accomplishment by ENLTT is the Ornamental Research Circular authored mainly by ENLTT members, and printed by the Ohio Agricultural Research and Development Center (OARDC), and OSU Extension. This circular is developed each year at the end of the growing season so it will be available in January for the OSU Nursery Short Course. The goals of this bulletin are to provide summaries of the past growing season relative to pests and diseases, and cultural and environmental factors for ornamental plants; reports of ongoing ornamental research at OSU in the ornamental horticulture area; perspectives on horticultural research and programming; and information on how to contact and access information from OSU's horticultural educators, especially with regard to ENLTT. All four coeditors are members of ENLTT. This ornamental circular is the most widely requested publication at OARDC, with 5,000 copies printed each year.

Many successful educational programs have been offered by ENLTT. The team has provided strong leadership to the OSU Nursery Short Course, the third largest nursery and landscape short course and trade show in the country. Two team members are the cochairs of the short course. Many team members are speakers, moderators, and speaker greeters for the short course. The short course and trade show drew a record 13,711 attendees in 2000, breaking the 1999 record of 11,901! In addition, ENLTT members organized several regional schools including the Plant Health Care Workshop, and Conifer, Deciduous Shrub, and Perennial Schools. These schools have attracted large attendance and received excellent evaluations.

\section{Strong financial industry support for ENLTT}

ENLTT has received more than $\$ 230,000$ from ONLA since 1993 and additional funding from the Ohio Chapter of the International Society of Arboriculture since 1996. From 1999 to 2001, ONLA has donated \$30,000 each year to ENLTT. With these funds, ENLTT members have greatly improved their teaching and problem-solving skills through computer upgrades, weekly horticulture in-servicing during BYGL conference calls, attending horticultural study tours, and adding horticultural references.

Team funds have been used to cover long distance phone charges for BYGL conference and faxing BYGL and to purchase computers, cameras, and reference books. Other expenses included travel to team meetings, and horticulture study tours. ENLTT members have greatly sharpened their horticultural skills and improved computer capabilities as a direct result of the financial support.

\section{Team membership and culture}

Team membership is based on interest and commitment to the vision and mission of the team. The vision of ENLTT is to grow with our partners toward a sustainable future. The mission of ENLTT is to empower people to make informed decisions by improving the process of discovery and delivery of effective educational resources. Potential members are encouraged to participate in ENLTT activities to see if they would like to join. Currently, there are 38 members on the ENLTT.

Each team member is involved in the decision-making 
process. Team members vote on important issues such as fund expenditures, projects, and the overall direction of the team. If our team is divided on an issue, we will then have more discussion on it to reach a team consensus. If a consensus cannot be reached, our team will not act on that issue. Our team will not let one person force a decision on the rest of the team. Often, subcommittees are formed to tackle specific projects such as recertification manuals for ONLA, team study tours, and a horticultural calendar. The ENLTT has a team coordinator who works closely with ONLA and OSU Extension administration. However, the team coordinator does a great job delegating authority to team members and sharing successes with everyone else. There are at least three team meetings a year where members decide on the important issues in addition to weekly BYGL conference calls during the growing season. ENLTT also monitors the needs of the green industry groups by surveys, meetings, site visits, and program evaluations.

\section{Team synergy}

Tremendous synergy has resulted from the teamwork. Many accomplishments have been achieved that would not have occurred without teamwork. ENLTT team members help each other out when asked. Many programs such as the Master Gardener programs, the Plant Health Care Workshop, regional plant material schools, county field days, and many landscape seminars, were conducted successfully with relative ease since team members knew that they could count on each other for help. Numerous publications of papers, bulletins, fact sheets, and newsletters could only have occurred through joint efforts spawned by the team.

One of the greatest benefits of the teamwork is the weekly in-servicing during BYGL conference calls. Every member reports the problems in their area and all members help diagnose these problems. Everyone benefits from the diagnostic discussions that occur each week. Team members are able to constantly sharpen their horticultural problemsolving skills. In addition, team members never feel alone when they are faced with challenging questions since they know they can turn to team members for help, especially during the BYGL season, which runs from April to October.

\section{Conclusion}

The concept of ENLTT works well for OSU Extension because all team members benefit and our administration strongly supports our efforts. Team members have significantly enhanced their professional development, sharpened their horticultural skills, improved their educational programs, and greatly expanded their teaching resources as a direct result of their team involvement. More timely and practical educational resources, such as the weekly BYGL and Ornamental Research Circular, are developed and provided to the green industry and gardening public in Ohio. In 1999, BYGL survey respondents estimated that BYGL increased their profitability by $\$ 122,500$. A strong partnership has been formed between ENLTT and ONLA, as demonstrated by the significant funding support, which has exceeded \$230,000 since 1993. Since the development of ENLTT, 22 highly active, creative, and diverse commodity and issue teams have been formed at OSU Extension. We strongly believe that extension professionals in other states could take the components from our model and make them fit their own situation.

\section{Literature cited}

Chatfield, J.A., J.F. Boggs, and D.J. Shetlar. 1996. The Buckeye Yard and Garden Line. HortTechnology 6(3):280-281.

Gao G.Y., P.J. Bennett, J.F. Boggs, J.A. Chatfield, D.D. Dyke, J.C. Martin, D.J. Shetlar, R.H. Zondag, A.K. Stone, and E.A. Draper. 2000. 1999 Buckeye Yard and Garden Line (BYGL) evaluation survey, p.15-19. In: Ornamental plants annual reports and research reviews. Ohio State Univ. Ext. Agr. Res. Dev. Ctr. Spec. Circ. 173.

Lipman-Blumen, J. and H.J. Leavitt. 1999. Hot groups "with attitude": A new organizational state of mind. Organizational Dynamics 27(4):63-73.

Weiss, D.J. 1990. Self-directed teams: The true measure of effectiveness. Supervisory Mgt. 35(12):4. 